\title{
PRESTASI BELAJAR MAHASISWA PROGRAM STUDI PAI FITK UIN RADEN FATAH PALEMBANG ANGKATAN 2014 DALAM MATA KULIAH BAHASA ARAB
}

\begin{abstract}
Abdurahmansyah, Ismail Sukardi, Nyayu Soraya

Dosen Fakultas Ilmu Tarbiyah dan Keguruan UIN Raden Fatah Palembang
\end{abstract}

\begin{abstract}
The curriculum is based on the State Islamic University Raden Fatah Palembang, Arabic courses included in Component (MKU) to be followed by all students of various faculties and pogram Studies. While Raden Fatah Palembang UIN Students come from a variety of different educational backgrounds some of which comes from MAN and SMU. Among them there are already studying Arabic and some have not even never at all to learn Arabic because their school curriculum tailored to each. Therefore whether their learning achievement in the subject of Arabic was also no difference, then there should be research to prove it.

The purpose of this study was to determine differences in the achievement of students whose educational background Madrasah Aliyah (MAN) and student backgrounds of State High School (SMU) in the subject of Arabic.

Starting from the idea of achievement (output) students in learning that can be influenced by various components one of which is the input that students with a variety of factors that influence both internally and externally. The hypothesis proposed in this study was the difference in the achievement of students who come from MAN and students from SMU in the course Arabic.

The method used in this research is descriptive analysis method to study the documentation. The analysis of the data using a statistical approach to the bivariate komparasional techniques. Once the data is analyzed, the results showed that the two variables are students who come from MAN and students from $S M U$, equally distributed normally, as well as two variations equally homogenous and then later on the results of hypothesis testing using the formula $t$ and results hypothesis testing indicate that Ho is accepted and Ha rejected.

Thus we can conclude that the achievement of students whose educational background Madrasah Aliyah (MAN) and student educational background School of Public Affairs (SMU) in the subject of Arabic turns out the difference is not significant. It means that there is a difference between the two although the difference was very little. So it means that students from SMU can follow courses in Arabic.
\end{abstract}

Keywords: Achievement, Learning, Arabic. 


\section{PENDAHULUAN}

UIN sebagai Perguruan Tinggi Islam, memiliki tujuan antara lain, mencetak tenaga ahli dan sarjana muslim yang memiliki keahlian dalam berbagai cabang. Agama Islam yang relevan dan berorientasi pada kebutuhan dan permasalahan nyata yang dihadapi oleh ummat Islam sesuai dengan tuntutan zaman.

Karena sebagian besar literatur ilmu-ilmu Agama Islam itu berbahasa Arab, maka penguasaan Bahasa Arab untuk Mahasiswa IAIN/UIN adalah merupakan hal yang mutlak. (Munawir, 1985; 134).

Melalui Sarjana UIN inilah diharapkan ajaran Islam berkembang sesuai dengan proporsinya, yaitu Islam yang dinamis dan memberi kontribusi terhadap peradaban umat manusia, untuk itulah sejak IAIN yang sekarang beraluh status menjadi UIN berdiri sampai sekarang telah mengalami kemajuan dan perkembangan yang cukup pesat baik fisik maupun non fisik.

Dalam bidang non fisik pengembangannya lebih diarahkan pada peningkatan sumber daya manusia antara lain dengan penambahan Fakultas dan Program Studi di UIN Raden Fatah Palembang yang kini telah memiliki 8 Fakultas dengan 20 jurusan. Dengan dibukanya program studi baru tersebut, maka dari hasil eksplorasi diperoleh informasi bahwa mahasiswa UIN Palembang itu berasal dari berbagai latar belakang pendidikan seperti dari Madrasah Aliyah Negeri/Swata (MAN/MAS), Sekolah Menengah Umum Negeri/swasta (SMUN, SMUS), dan dari Sekolah Kejuruan (STM, SMEA). Karena beragamnya latar belakang pendidikan mahasiswa tersebut maka dalam penelitian ini penulis mencoba membatasi objek penelitiannya hanya terhadap mahasiswa yang berasal dari MAN dan SMUN, sementara yang lainnya diabaikan.

Dalam kurikulum yang digunakan baik di MAN ataupun di SMUN ternyata mereka menggunakan kurikulum tahun 2012 dimana pada kurikulum MAN terdapat pelajaran Bahasa Arab sedangkan pada kurikulum SMUN tidak terdapat pelajaran Bahasa Arab.

Sementara pada kurikulum UIN Raden Fatah ditetapkan bahwa Bahasa Arab termasuk mata kuliah umum (MKU), yang artinya bahwa Bahasa Arab termasuk pada mata kuliah Universitas yang harus dan wajib diikuti oleh semua mahasiswa dari berbagai Fakultas dan Program Studi. 
Maka permasalahannya sekarang ialah ingin mengetahui hasil belajar prestasi yang di peroleh mahasiswa yang belatar belakang pendidikan yang berbeda itu di dalam bidang studi Bahasa Arab.

Berdasarkan uraian pada latar belakang di atas, selanjutnya di rumuskan permasalahanya dalam bentuk pertanyaan sebagai berikut:

1. Bagaimana prestasi belajar mahasiswa yang berlatar belakang pendidikan dari MAN dalam mata kuliah Bahasa Arab.

2. Bagaimana prestasi belajar mahasiswa yang berlatar belakang pendidikan dari SMUN dalam mata kuliah Bahasa Arab.

3. Apakah Ada perbedaan antara prestasi belajar mahasiswa yang berlatar belakang pendidikan MAN, dan mahasiswa yang berlatar belakang pendidikan SMUN dalam mata kuliah Bahasa Arab.

Yang dimaksud dengan istilah prestasi dalam rumusan masalah di atas yaitu Nilai Akhir Mata Kuliah (NAM) yang terdiri dari Sisipan (SSP), Tugas Terstruktur Mandiri (TTM), Ujian Tengah Semester (UTS) dan Ujian Akhir Semester (UAS) dengan rumus:

$$
\mathrm{N} A M=\underline{1 S S P+2 T T M+3 U T S+4 U A S}
$$

10

\section{Teori Prestasi Belajar}

Kata prestasi belajar terdiri dari dua suku kata, yaitu prestasi dan belajar. Di dalam Kamus Besar Bahasa Indonesia, yang dimaksud dengan prestasi adalah "hasil yang telah dicapai dilakukan, dikerjakan". Adapun belajar menurut pengertian secara psikologis, adalah merupakan suatu proses perubahan yaitu perubahan tingkah laku sebagai hasil dari interaksi dengan lingkungannya dalam memenuhi kebutuhan hidupnya. Perubahan-perubahan tersebut akan nyata dalam seluruh aspek tingkah laku. Menurut Slameto pengertian belajar dapat Dalam Kamus Besar Bahasa Indonesia (1990: 700) prestasi adalah hasil yang dicapai (dari yang telah dilakukan dan dikerjakan). Dengan kata lain prestasi adalah hasil yang menggembirakan dari suatu kegiatan yang telah dikerjakan, baik secara perorangan maupun kelompok dalam bidang tertentu.

Menurut Usman (2002: 21) belajar adalah usaha melatih daya-daya agar berkembang sehingga dapat berfikir, mengingat dan sebaginya. Sedangkan, 
menurut Slameto (2003: 2) belajar adalah suatu proses usaha yang dilakukan seseorang untuk memperoleh suatu perubahan tingkah laku yang secara keseluruhan, sebagai hasil pengalamannya sendiri dalam interaksi dengan lingkungannya. Lebih lanjut Soemanto (1998: 104) menjelaskan bahwa belajar dapat didefenisikan sebagai proses dimana tingkah laku ditimbulkan atau diubah melalui latihan atau pengalaman. Dengan demikian belajar adalah perubahan tingkah laku melalui pengalaman dan latihan. Selain itu, belajar juga membawa perubahan-perubahan dalam tingkah laku dari organisme.

Sardiman (2008: 20) mengungkapkan bahwa belajar itu senantiasa merupakan perubahan tingkah laku atau penampilan dengan serangkaian kegiatan misalnya dengan membaca, mengamati, mendengarkan, meniru dan sebagainya.

Dari pengertian prestasi dan belajar di atas, dapat diambil suatu pengertian bahwa prestasi belajar adalah hasil yang diperoleh baik berupa pengetahuan, sikap maupun keterampilan yang mengakibatkan perubahan tingkah laku sebagai hasil dari kegiatan belajar. Dalam pengertian yang lebih praktis, prestasi belajar dapat diartikan dengan penguasaan pengetahuan, sikap dan keterampilan oleh seorang siswa yang dikembangkan melalui mata pelajaran dan indikatornya ditunjukkan dengan nilai hasil tes yang diberikan oleh guru.

\section{Bentuk-bentuk Prestasi Belajar}

Tujuan pendidikan yang ingin dicapai, dapat dikategorikan ke dalam tiga bidang yakni: bidang kognitif, bidang afektif, dan bidang psikomotor. Ketigatiganya bukan berdiri sendiri, melainkan merupakan suatu kesatuan yang tidak dapat dipisahkan bahkan membentuk hubungan yang hirarkis. Sebagai tujuan yang hendak dicapai, ketiga-tiganya harus nampak sebagai tujuan yang hendak dicapai. Ketiga-tiganya harus nampak sebagai hasil belajar siswa di sekolah. Oleh sebab itu ketiga aspek tersebut harus dipandang sebagai hasil belajar siswa dari proses pengajaran. Adapun bentuk-bentuk hasil belajar tersebut seperti yang dikemukakan oleh AF. Tangyong dalam sebuah artikel internet dengan situs http://makalahpendidikan-sudirman.blogspot.com/2011/11/4.html meliputi:

a. Hasil Belajar Kognitif

Bentuk hasil belajar ini meliputi beberapa aspek sebagai berikut: 
1) Tipe hasil belajar pengetahuan hafalan (knowledge) Pengetahuan hafalan, sebagai terjemahan dari knowledge. Cakupan pengetahuan hafalan termasuk pula pengetahuan yang sifatnya faktual, disamping pengetahuan yang mengenai hal-hal yang perlu diingat kembali. Seperti: batasan, peristilahan, pasal, hukum, bab, ayat, rumus dan sebagainya. Dari sudut respon belajar siswa pengetahuan itu dihafal, diingat agar dapat dikuasai dengan baik. Ada beberapa cara untuk menguasai atau menghafal misalnya bicara berulang-ulang, menggunakan teknik mengingat. Hal ini dapat dilakukan dengan pembuatan ringkasan dan sebagainya.

2) Tipe hasil belajar pemahaman (comprehention)

Tipe hasil belajar pemahaman lebih tinggi satu tingkat dari tipe prestasi belajar pengetahuan hafalan. Pemahaman memerlukan kemampuan menangkap makna atau arti dari suatu konsep, untuk itu diperlukan adanya hubungan atau pertautan antara konsep dengan makna yang ada dalam konsep yang dipelajari. Ada tiga macam pemahaman yang berlaku umum yaitu; pemahaman terjemahan, yakni kesanggupan memahami sesuatu makna yang terkandung di dalamnya. Misalnya memahami kalimat dari bahasa yang satu ke bahasa yang lain, mengartikan lambang negara dan sebagainya. Pemahaman penafsiran, misalnya memahami grafik, menghubungkan dua konsep yang berbeda, membedakan yang pokok dan yang bukan pokok. Dan pemahaman ekstrapolasi yakni kesanggupan melihat di balik yang tertulis, tersirat dan tersurat, meramalkan sesuatu atau memperluas wawasan.

3) Tipe hasil belajar penerapan (Aplikasi)

Aplikasi adalah kesanggupan menerapkan dan mengabstraksi suatu konsep, ide, rumus dan hukum dalam situasi yang baru. Misalnya memecahkan persoalan dengan menggunakan rumus tertentu, menerapkan suatu dalil atau hukum dalam suatu persoalan dan sebagainya.

4) Tipe hasil belajar analisis 
Analisis adalah kesanggupan memecahkan dan menguraikan suatu integritas (kesatuan yang utuh) menjadi unsur-unsur atau bagianbagian yang mempunyai arti. Analisis merupakan tipe prestasi belajar sebelumnya, yakni pengetahuan dan pemahaman aplikasi. Kemampuan menalar pada hakikatnya merupakan unsur analisis, yang dapat memberikan kemampuan pada siswa untuk mengkreasi sesuatu yang baru, seperti: memecahkan, menguraikan, membuat diagram, memisahkan, membuat garis dan sebagainya.

5) Tipe hasil belajar sintesis

Sintesis adalah tipe hasil belajar, yang menekankan pada unsur kesanggupan menguraikan suatu integritas menjadi bagian yang bermakna, pada sintesis adalah kesanggupan menyatukan unsur atau bagian menjadi satu integritas. Beberapa bentuk tingkah laku yang operasional biasanya tercermin dalam kata-kata: mengkategorikan, menggabungkan, menghimpun, menyusun, mencipta, merancang, mengkonstruksi, mengorganisasi kembali, merevisi, menyimpulkan, menghubungkan, mensistematisasi, dan lain-lain.

6) Tipe hasil belajar evaluasi

Evaluasi adalah kesanggupan memberikan keputusan tentang nilai sesuatu berdasarkan judment yang dimilikinya. Tipe prestasi belajar ini dikategorikan paling tinggi dan terkandung dalam semua tipe prestasi belajar yang telah dijelaskan sebelumnya. Dalam tipe prestasi hasil belajar evaluasi, tekanannya pada pertimbangan mengenai nilai, mengenai baik tidaknya, tepat tidaknya menggunakan kriteria tertentu. Dalam proses ini diperlukan kemampuan yang mendahuluinya, yakni pengetahuan, pemahaman aplikasi, analisis dan sintesis. Tingkah laku yang operasional dilukiskan pada kata-kata menilai, membandingkan, mengkritik, menyimpulkan, mendukung, memberikan pendapat dan lain-lain. 
b. Hasil Belajar Afektif

Bidang afektif berkenaan dengan sikap dan nilai. Sikap seseorang dapat diramalkan perubahannya, bila orang yang bersangkutan telah menguasai bidang kognitif tingkat tinggi. Hasil belajar bidang, kurang mendapat perhatian dari guru dan biasanya dititikberatkan pada bidang kognitif semata-mata. Tipe hasil belajar yang afektif tampak pada siswa dalam berbagai tingkah laku, seperti: atensi, perhatian terhadap pelajaran, disiplin, motivasi belajar, menghargai guru dan teman sekelas, kebiasaan belajar dan lain-lain. Ada beberapa tingkatan bidang afektif, sebagai tujuan hasil belajar antara lain adalah sebagai berikut:

1. Receiving/attending, yakni semacam kepekatan dalam menerima rangsangan (stimulus) dari luar yang datang ke dalam diri siswa baik dalam bentuk masalah situasi gejala dan lain-lain. Dalam tipe ini termasuk kesadaran, keinginan yang ada dari luar.

2. Responding atau jawaban, yakni reaksi yang diberikan kepada seseorang terhadap stimulasi yang datang dari luar. Yang termasuk dalam hal ini adalah ketetapan reaksi, perasaan, kepuasan dapat menjawab stimulasi yang berasal dari luar.

3. Evaluing (penilaian), yakni berkenaan dengan nilai dan kepercayaan terhadap gejala atau stimulasi tadi. Yang termasuk dalam evaluasi ini adalah kesediaan menerima nilai, latar belakang atau pengambilan pengamalan untuk menerima nilai dan kesepakatan terhadap nilai yang diterimanya.

4. Organisasi, yakni pengembangan nilai ke dalam satu sistem organisasi, termasuk menentukan hubungan satu nilai dengan nilai yang lain, kemantapan serta prioritas nilai yang dimilikinya. Yang termasuk dalam organisasi ini adalah konsep tentang nilai, organisasi dari pada sistem nilai.

5. Karakteristik nilai atau internalisasi nilai, hal ini merupakan keterpaduan semua sistem nilai yang telah dimiliki seseorang, yang mempengaruhi pola kepribadian dan tingkah laku. 
c. Tipe Hasil Belajar Psikomotor

Hasil belajar psikomotor tampak dalam bentuk keterampilan (skill) dan kemampuan bertindak individu (seseorang). Ada 6 tingkatan keterampilan antara lain adalah:

1) Gerakan refleks (keterampilan pada gerakan yang tidak sadar).

2) Keterampilan pada gerakan-gerakan dasar.

3) Kemampuan konseptual, termasuk di dalamnya membedakan visual, membedakan auditif motorik dan lain-lain.

4) Kemampuan di bidang fisik, misalnya kekuatan, keharmonisan dan ketepatan.

5) Gerakan-gerakan skill, hal ini mulai dari keterampilan sederhana sampai pada keterampilan yang sangat kompleks

6) Kemampuan yang berkenaan dengan non decursivo komunikasi, seperti gerakan interpretatif dan sebagainya.

\section{Faktor-faktor yang Mempengaruhi Prestasi Belajar}

Secara global, faktor-faktor yang mempengaruhi belajar siswa dapat kita bedakan menjadi dua macam:

\section{a. Faktor dari dalam diri siswa (intern)}

1) Faktor Jasmani

Dalam faktor jasmaniah ini dapat dibagi menjadi dua yaitu faktor kesehatan dan faktor cacat tubuh.
a) Faktor kesehatan
b) Cacat tubuh

2) Faktor psikologis
a) Intelegensi
b) Perhatian
c) Bakat
d) Minat
e) Sikap siswa
f) Motivasi
g) Kematangan
h) Kesiapan 
3) Faktor kelelahan

Kelelahan jasmani dan rohani dapat mempengaruhi prestasi belajar dan agar siswa belajar dengan baik haruslah menghindari jangan sampai terjadi kelelahan dalam belajarnya seperti lemas tubuh. Sehingga perlu diusahakan kondisi yang bebas dari kelelahan rohani seperti memikirkan masalah yang berarti tanpa istirahat, mengerjakan sesuatu karena terpaksa tidak sesuai dengan minat dan perhatian. Ini semua besar sekali pengaruhnya terhadap pencapaian prestasi belajar siswa. Agar siswa selaku pelajar dengan baik harus tidak terjadi kelelahan fisik dan psikis.

\section{b. Faktor yang berasal dari luar (faktor ekstern)}

Faktor ekstern yang berpengaruh terhadap prestasi belajar dapatlah dikelompokkan menjadi tiga faktor yaitu faktor keluarga, faktor sekolah dan faktor masyarakat.

\section{1) Faktor keluarga}

Faktor keluarga sangat berperan aktif bagi siswa dan dapat mempengaruhi dari keluarga antara lain: cara orang tua mendidik, relasi antara anggota keluarga, keadaan keluarga, pengertian orang tua, keadaan ekonomi keluarga, latar belakang kebudayaan dan suasana rumah.

Menurut Hamalik (2002), mengemukakan bahwa keadaan keluarga sangat mempengaruhi prestasi belajar anak karena dipengaruhi oleh beberapa faktor dari keluarga yang dapat menimbulkan perbedaan individu seperti kultur keluarga, pendidikan orang tua, tingkat ekonomi, hubungan antara orang tua, sikap keluarga terhadap masalah sosial dan realitas kehidupan.

a) Pengertian dari orang tua

Bila anak sedang belajar jangan diganggu dengan tugas-tugas rumah. Kadang-kadang anak mengalami lemah semangat, orang tua wajib memberi pengertian dan mendorongnya sedapat mungkin untuk mengatasi kesulitan yang dialaminya.

b) Keadaan ekonomi keluarga

Menurut Slameto (2003) bahwa keadaan ekonomi keluarga erat hubungannya dengan belajar anak. Anak yang sedang belajar selain terpenuhi kebutuhan pokoknya, misalnya makanan, pakaian, perlindungan kesehatan, dan 
lain-lain, juga membutuhkan fasilitas belajar seperti ruang belajar, meja, kursi, penerangan, alat tulis menulis, dan sebagainya.

c) Latar belakang kebudayaan

Tingkat pendidikan atau kebiasaan di dalam keluarga mempengaruhi sikap anak dalam belajar http://donipengalaman9.wordpress.com/Prestasi Belajar.docx ftn23. Oleh karena itu perlu kepada anak ditanamkan kebiasaan-kebiasaan baik, agar mendorong tercapainya hasil belajar yang optimal.

d) Suasana rumah

Suasana rumah merupakan situasi atau kejadian yang sering terjadi di dalam keluarga di mana anak-anak berada dan belajar. Suasana rumah yang gaduh, bising dan semwarut tidak akan memberikan ketenangan terhadap diri anak untuk belajar.

2) Faktor sekolah

Faktor sekolah dapat berupa cara guru mengajar, alat-alat pelajaran, kurikulum, waktu sekolah, interaksi guru dan murid, disiplin sekolah, dan media pendidikan, yaitu:
a) Guru dan cara mengajar
b) Model pembelajaran
c) Alat-alat pelajaran
d) Kurikulum

Menurut Slameto bahwa kurikulum yang tidak baik akan berpengaruh tidak baik terhadap proses belajar maupun prestasi belajar siswa.

e) Waktu sekolah

Waktu sekolah adalah waktu terjadinya proses belajar mengajar di sekolah, waktu sekolah dapat pagi hari, siang, sore bahkan malam hari. Waktu sekolah juga mempengaruhi belajar siswa.

f) Interaksi guru dan murid

g) Disiplin sekolah

h) Media pendidikan

3) Faktor Lingkungan Masyarakat 
Faktor yang mempengaruhi terhadap prestasi belajar siswa antara lain teman bergaul, kegiatan lain di luar sekolah dan cara hidup di lingkungan keluarganya. Selain faktor-faktor di atas ada beberapa faktor yang mempengaruhi prestasi belajar, terutama pada beberapa jenis aspek perbedaan serta cirinya. Hal ini sebagaimana diungkapkan oleh Hamalik (2001: 181-183) yaitu: Kecerdasan (inteligence), bakat (aptitude), keadaan jasmaniah (physical fitness), latar belakang keluarga (home background), dan hasil belajar (academic achievement).

Kecerdasan merupakan faktor yang mempengaruhi belajar, ini dikarenakan siswa yang mempunyai kecerdasan (IQ) yang tinggi, umumnya mempunyai tingkat perhatian yang lebih baik, belajar cepat, kurang memerlukan latihan dan mampu menyesuaikan tugas atau pekerjaannya secara singkat. Begitu juga sebaliknya bagi siswa yang kurang tingkat kecerdasannya umumnya belajar lebih lamban, memerlukan banyak latihan yang bermakna. Bakat juga mempengaruhi prestasi belajar, sikap, minat dan lainnya.

Keadaan jasmaniah seperti gangguan penyakit akan mempengaruhi efisiensi dan kegairahan belajar, karena badannya mudah lelah dan kurang berminat melakukan kegiatan. Latar belakang keluarga juga mempengaruhi prestasi belajar, hal ini dikarenakan banyak kultur yang bersumber dari keluarga yang dapat menimbulkan perbedaan individual, seperti kultur dalam keluarga, tingkat pendidikan orang tua, tingkat ekonomi, hubungan antara kedua orang tuanya, sikap keluarga terhadap masalah-masalah sosial, realita kehidupan, semuanya akan memberikan pengalaman kepada anak-anak dan menimbulkan perbedaan dalam minat, apresiasi, sikap, pemahaman ekonomis, perbedaan bahasa, kebiasaan berbicara dan lain-lain.

Pemilihan media pembelajaran juga bisa mempengaruhi hasil belajar siswa. Oleh sebab itu Hamalik (2001: 101) menjelaskan bahwa pemilihan media pembelajaran hendaknya mempertimbangkan beberapa hal berikut:

a. Faktor manusiawi yang berkenaan dengan unsur-unsur peserta didik, pengajar dan tenaga teknisi.

b. Faktor komunikasi yang efektif, yang berkenaan dengan unsur-unsur peserta didik, isi/materi pembelajaran dan tujuan yang hendak dicapai. 
c. Faktor biaya yang memadai, yang berkaitan dengan unsur-unsur tujuan yang hendak dicapai, pasaran dan keadaan.

d. Faktor hambatan-hambatan praktis yang berkaitan dengan unsur-unsur keadaan, waktu dan fasilitas.

Keempat faktor tersebut perlu dipertimbangkan secara komprehensif dalam rangka memilih media pembelajaran yang berguna dan berhasil sehingga hasil yang diperoleh akan menjadi hasil yang maksimal.

\section{Ukuran Prestasi Belajar}

Ada beberapa alternatif norma pengukuran prestasi belajar sebagai indikasi keberhasilan belajar siswa setelah mengikuti proses belajar mengajar.

Dewasa ini telah terjadi peningkatan ukuran keberhasilan belajar siswa. Siswa yang berhasil menyelesaikan soal-soal ujian sebanyak $75 \%$ sampai $80 \%$ dari seluruh soal-soal, dianggap memenuhi standar kelulusan. Simbol penilaian dengan huruf, umumnya dinegara kita diberlakukan untuk tingkat perguruan tinggi. Berdasarkan norma ukuran tersebut, tidak ada keharusan guru untuk menggunakan satu norma diatas secara kaku. Norma ukuran manapun bisa digunakan untuk acuan ukuran terhadap prestasi.

\section{METODE PENELITIAN}

1. Penentuan Metode

Metode yang digunakan dalam penelitian ini adalah metode Deskriptif Analis, data-data yang di peroleh dihimpun, dianalisis, diterjemahkan dan dijabarkan (dideskripsikan) sehingga pada sampai kesimpulan yang diharapkan dan kesimpulan terhadap sampel sama dengan kesimpulan terhadap populasi.

\section{Jenis Data}

Data pokok yang akan di himpun dalam penelitian ini, pertama adalah data tentang prestasi mahasiswa, yaitu berupa nilai prestasi mahasiswa dalam mata kuliah Bahasa Arab, selama satu semester yaitu semester IV untuk mahasiswa Fakultas Ilmu Tarbiyah dan Keguruan Prodi PAI angkatan 2014. Adapun jenis data yang kedua adalah data tentang latar belakang pendidikan mereka sebelum masuk UIN Raden Fatah Palembang". 


\section{Sumber data}

Jenis data di atas bersumber dari dokumen-dokumen yang di peroleh dari Jurusan PAI Fakultas Tarbiyah, dan dari Bagian Akademik Fakultas Ilmu Tarbiyah UIN Raden Fatah Palembang.

a. Lokasi Penelitian

Penelitian ini dilaksanakan di Pogram Studi PAI FITK UIN Raden Fatah Palembang" dengan alasan karena di lokasi tersebut terdapat masalah yang harus diteliti. Alasan lainnya karena lokasi tersebut merupakan tempat penulis bertugas sebagai dosen tetap di Prodi tersebut dan sekaligus sebagai pengampu Mata Kuliah Bahasa Arab.

b. Populasi dan sampel.

1. Populasi

Penelitian ini melibatkan mahasiswa Fakultas Tarbiyah program S-1 Jurusan PAI semester IV Angkatan 2014.

Berdasarkan data yang di peroleh seluruh mahasiswa Fakultas Tarbiyah jurusan PAI berjumlah 288 yang mana terdiri dari 82 laki-laki dan 206 perempuan yang berasal dari berbagi sekolah negeri ataupun Swasta bahkan dari sekolah kejuruan. Tetapi yang menjadi objek penelitian di sini hanyalah mahasiswa yang berasal dari MAN dan SMUN sementara mahasiswa yang lain diabaikan.

Setelah diidentifikasi ternyata 90 orang berasal dari MAN mereka pernah belajar bahasa arab, sementara 30 orang berasal dari SMUN mereka tidak belajar bahasa arab sama sekali sesuai dengan kurikulum sekolah mereka masingmasing.

Jadi dalam populasi ini terdapat dua kelompok mahasiswa yang berasal dari MAN dan kelompok yang tidak belajar Bahasa Arab yang diwakili oleh mahasiswa yang berasal dari SMUN.

2. Sampel

Untuk sampelnya masing-masing di ambil 100\% yaitu MAN 90 orang dan SMUN 30 orang. 


\section{Pengumpulan data}

Tehnik pengumpulan data dalam penelitian ini di lakukan dengan studi Dokumentasi, karena data-data yang akan di teliti bersumber dari dokumendokumen yang masih harus di analisa dan diterjemakan.

5. Analisis Data

Pengelolah data dilakukan dengan pendekatan statistik guna menjawab pertanyaan yang di ajukan dalam perumusan masalah dan untuk membuktikan Hipotesis yang di ajukan. Adapun langkah -langkahnya adalah:

a. Uji Normalitas, dengan terlebih dahulu menentukan rentang nilai, membuat tabel, distribusi frekuensi, menentukan nilai rata-rata standar deviasi, menghitung harga chi kuadrat serta membandingkannya dengan harga chi kuadrat tabel pada taraf signifikansi $1 \%$.

b. Uji Homoginitas, dengan cara menghitung harga $F$ hitung, menentukan derajat kebebasan dan membandingkanya dengan harga $F$ tabel pada taraf signifikasi $1 \%$ dengan kriteria data itu dikatakan homogen jika harga $\mathrm{F}$ hitung lebih kecil dari harga $\mathrm{F}$ tabel, sebaliknya jika harga $\mathrm{F}$ hitung lebih besar dari harga $\mathrm{F}$ tabel maka dikatakan tidak homogen.

c. Uji Beda, dengan terlebih dahulu menentukan standar deviasi gabungan, menentukan derajat kebebasan, menghitung harga $t$ hitung dan memnandingkannya, dengan harga t table pada taraf signifikansi 1\%. Jika harga $t$ hitung lebih besar dari harga $t$ table berarti ada perbedaan dan jika $\mathrm{t}$ terhitung lebih kecil dari $\mathrm{t}$ table berarti tidak ada perbedaan.

d. Pengujian Hipotesis.

Sesuai dengan hipotesis yang diajukan yaitu:

Ho (Hipotesis Nihil) artinya tidak ada perbedaan antara mahasiswa yang berlatar belakang pendidikan MAN dan SMUN dalam bidang studi Bahasa Arab. Ha (Hipotesis Alternatif) artinya ada perbedaan antara mahasiswa yang berlatar belakang pendidikana MAN dan SMUN. Maka berdasarkan pengolahan dengan menggunakan rumus " $\mathrm{tt}$ ", jika to<tt berarti Ho diterima dan Ha ditolak, tetapi sebaliknya jika to >tt maka Ho ditolak dan Ha diterima. 


\section{HASIL PENELITIAN}

Prestasi mahasiswa yang berlatar belakang pendidikan MAN dalam mata kuliah Bahasa Arab penulis tetapkan sebagai variable dependen yaitu variabel terikat, dengan diberi kode nama variable $(\mathrm{X})$.

1. Data

Dibawah ini penulis cantumkan data nilai mahasiswa yang berlatar belakang pendidikan MAN sebanyak 90 orang.

Tabel 2:

Hasil nilai komulatif dari sejumlah 90 orang mahasiswa Fakultas Ilmu Tarbiyah dan Keguruan Podi PAI semester IV Angkatan 2014 yang berasal dari MAN dalam mata kuliah Bahasa Arab

\begin{tabular}{|l|l|l|l|l|l|l|l|l|l|}
\hline 77 & 82 & 84 & 71 & 66 & 76 & 73 & 68 & 78 & 72 \\
\hline 77 & 64 & 61 & 62 & 69 & 73 & 57 & $\mathbf{5 7}$ & 77 & 84 \\
\hline 69 & 59 & 68 & 85 & 61 & 77 & 66 & 83 & 82 & 78 \\
\hline 76 & 85 & 80 & 80 & 78 & 70 & 76 & 81 & 76 & 85 \\
\hline 80 & 77 & 76 & 78 & 80 & $\mathbf{8 9}$ & 60 & 77 & 80 & 68 \\
\hline 71 & 78 & 79 & 75 & 77 & 78 & 76 & 75 & 76 & 76 \\
\hline 69 & 80 & 75 & 70 & 85 & 78 & 84 & 79 & 64 & 64 \\
\hline 64 & 64 & 75 & 83 & 75 & 64 & 83 & 64 & 64 & 76 \\
\hline 75 & 83 & 64 & 75 & 83 & 76 & 76 & 64 & 64 & 76 \\
\hline
\end{tabular}

\section{Analisis Data}

Dari deretan angka-angka di atas penulis mencoba menganalisanya dengan pendekatan statistik dan menguji normal atau tidaknya distribusi frekuensi dari sample di atas. Dan untuk mengetahui apakah sample tersebut normal atau tidak, dilakukan uji normalitas dengan terlebih dahulu:

a. Menentukan nilai tertinggi dan nilai terendah dari angka-angka di atas, maka diperoleh angka tertinggi (Xt) sebesar 89 dan angka terendah $(\mathrm{Xr})$ sebesar 57. Setelah angka-angka tersebut diperoleh kemudian langkah selanjutnya adalah: 
b. Mencari rentang (tabel range) yaitu untuk dijadikan sebagai patokan dalam menentukan kelas interval dan panjang interval dan diperoleh angka rentang sebesar 33. Angka tersebut diperoleh dari perhitungan $R=\mathrm{X}_{1}-\mathrm{X}_{2}+1$

c. Mencari kelas interval (K) diperoleh angka 7 yaitu hasil perhitungan dari $K=1+33 \log N$

d. Mencari panjang interval (P) diperoleh hasil angka 5 yaitu hasil perhitungan dari rentang dibagi kelas interval atau dengan rumus:

$\frac{N A M ; 1 S S P+2 T T M+3 U T S+4 U A S}{10}$

e. Membuat tabel distribusi frekuensi yang terdiri dari beberapa kolom:

Kolom pertama (kelas interval)

Yang terdiri dari 7 kelas, mulai dari nilai terendah sampai nilai tertinggi dengan panjang masing-masing 10.

Kolom kedua frekuensi (f) dari masing-masing kelas interval.

Kolom ketiga (X) ialah nilai titik tengah (mid point) yaitu dengan cara menjumlahkan nilai yang ada pada masing-masing kelas interval dibagi dua. Kolom keempat $\left(\mathrm{X}_{1}^{2}\right)$ yaitu kuadrat dari nilai titik tengah (mid point) di atas. Kolom kelima $\left(f_{1} X_{1}\right)$ yaitu hasil perkalian dari frekuensi dan nilai titik tengah (mid point).

Kolom keenam $\left(f_{1} \mathrm{X}_{1}^{2}\right)$ yaitu hasil kuadrat dari hasil perkalian frekuensi dan titik tengah (mid point).

Kolom ketujuh (fka) atau frekuensu kumulatif atas ialah hasil penjumlahan masing-masing frekuensi yang dimulai dari atas.

Kolom kedelapan (fkb) yaitu frekuensi kumulatif bawah ialah hasil penjumlahan masing-masing frekuensi yang dimulai dari bawah.

Kolom kesembilan ialah selisih deviasi (d).

Yang menjadi patokan pertama adalah nilai tertinggi dari nilai titik tengah yaitu 76. Dan selanjutnya baik nilai 76 sendiri begitu juga nilai-nilai ke atas dan bawah masing-masing dikurangi 76, yang hasilnya akan terlihat pada kolom ini.

Kolom kesepuluh (fd) ialah hasil perkalian dari frekuensi (f) dan selisih deviasi (d). 
Kolom kesebelas yaitu $\left(\mathrm{fd}^{2}\right)$ ialah hasil perkalian dan frekuensi (f) dan kuadrat selisih deviasi (d).

f. Menentukan harga Mean (M)

Harga mean dapat diperoleh dari jumlah hasil perkalian frekuensi dari nilai titik tengah (mid point) atau $\sum f_{1} \mathrm{X}_{1}$ dibagi jumlah $\sum f_{1}$ diperoleh hasilnya ialah 73,89 .

g. Menentukan median (md) yaitu hasil kali $1 / 2 n$ dikurangi frekuensi kumulatif bawah median dibagi median atau

$B b+P=\frac{(1 / 2 n-f k b)}{F}$ diperoleh hasil 74,9.

h. Menetukan modus (Mo) yaitu 3 kali median -2 kali mean atau $3 \mathrm{md}-2 \mathrm{~m}$ diperoleh hasil 76, 92.

i. Membuat kurva

Karena berdasarkan perhitungan di atas harga mean lebih kecil dari median dan median lebih kecil dari modus, maka kurva tersebut berbentuk juling negatif atau berposisi mendekati normal. Bentuk kurva yang berposisi juling negatif berarti menunjukkan bahwa nilai-nilai yang diperoleh lebih banyak bertumpu pada nilai-nilai tinggi.

j. Menentukan standar devisi (SD)

Yaitu hasil perkalian dari panjang interval terhadap akar dari jumlah kuadrat frekuensi kali selisih deviasi dibagi jumlah sampel dikurangi jumlah frekuansi kali selisih dibagi jumlah sampel kuadrat atau $S D=\sqrt{\sum \frac{f d^{2}}{N}-\frac{(\Sigma \mathrm{fd})^{2}}{N}}=7,62$

k. Membuat tabel frekuensi observasi dan ekspektasi yang terdiri dari delapan kolom.

Kolom 1 adalah kelas dan panjang interval yang terdiri dari nilai terendah sampai nilai tertinggi.

Kolom 2 adalah frekuensi dari nilai-nilai tersebut.

Kolom 3 adalah batas nyata hasil dari pengurangan dan penambahan terhadap nilai-nilai yang terdapat pada kelas interval, nilai rendah dikurangi 
0,5 dan nilai yang tinggi dikurangi 0,5 . Jadi kalau nilai pada kelas interval 87 - 91 maka batas nyatanya berarti 86,5 - 91,5.

Kolom 4 adalah mencari (luas kelas) 2 hitung yaitu hasil dari selisih batas nyata dikurangi mean dibagi standar deviasi (sd).

Kolom 5 mencari luas kelas dari tabel-tabel (2 tabel).

Kolom 6 adalah selisih luas kelas.

Kolom 7 ialah hasil dari selisih kelas dikalikan jumlah sampel atau $f e=s k \times N$.

Kolom 8 ialah nilai chi kuadrat yaitu hasil dari kuadrat frekuensi (f) dikurangi selisih kelas dibagi jumlah sampel (fe) atau $X=\frac{(f-f e)^{2}}{f e}=11,71$

1. Menemukan derajat kebebasan

Ialah hasil pengurangan dari kelas interval dikurangi 3 diperoleh hasil $\mathrm{K}-3=(7-3=4)$

m. Menemukan chi kuadrat tabel pada taraf signifikansi 5\% diperoleh hasilnya sebesar 13,277.

n. Penentuan normalitas

Pada perhitungan di atas diperoleh dari hasil chi kuadrat hitung sebesar 11,71 dan chi kuadrat tabel sebesar 13,277 berarti $\mathrm{X}_{\mathrm{ht}}^{2}<$ dari $\mathrm{X}_{\mathrm{tb}}^{2}$ hal itu dapat diinterpretasikan bahwa prestasi mahasiswa yang berlatar belakang pendidikan MAN dalam mata kuliah Bahasa Arab berdistribusi normal.

\section{Prestasi Mahasiswa yang Berlatar Belakang Pendidikan SMUN dalam}

\section{Bidang Studi Pendidikan Bahasa Arab}

Prestasi mahasiswa yang berlatar belakang pendidikan SMUN dalam mata pelajaran Bahasa Arab penulis tetapkan sebagai variabel Y.

Dibawah ini penulis cantumkan nilai-nilai mahasiswa berlatar pendidikan SMUN sebanyak 30 orang berikut analisis data dan pembahasannya.

1. Data

Di bawah ini adalah data nilai mahasiswa yang berasal dari SMUN. 
Tabel 3:

Hasil nilai kumulatif dari sejumlah 30 orang mahasiswa Fakultas Tarbiyah Jurusan PAI semester IV angkatan 2012 yang berlatar belakang pendidikan SMUN dalam mata kuliah Bahasa Arab

\begin{tabular}{|c|c|c|c|c|c|c|c|c|c|}
\hline $\mathbf{5 9}$ & 63 & 70 & 77 & 67 & 83 & 71 & $\mathbf{8 7}$ & 78 & 78 \\
\hline 65 & 72 & 78 & 77 & 76 & 75 & 82 & 75 & 83 & 75 \\
\hline 65 & 65 & 83 & 65 & 83 & 75 & 75 & 65 & 65 & 65 \\
\hline
\end{tabular}

\section{Analisis Data}

Agar data-data di atas berupa deretan angka-angka yang menunjukkan nilai hasil prestasi mahasiswa yang berasal dari SMUN dalam mata kuliah Bahasa Arab dapat disajikan dalam bentuk tabel distribusi frekuensi yang baik (teratur, ringkas, dan jelas) dan selanjutnya untuk menguji normalitas distribusi data-data tersebut dapat juga disajikan dalam bentuk tabel observasi dan eksploitasi maka perlu ditempuh langkah-langkah sebagai berikut:

a. Menentukan nilai tertinggi dan nilai terendah dari angka-angka di atas, maka diperoleh angka tertinggi $\left(\mathrm{X}_{\mathrm{t}}\right)$ sebesar 87 dan angka terendahnya $\left(\mathrm{X}_{\mathrm{r}}\right)$ sebesar 59.

Setelah angka-angka tersebut diperoleh kemudian langkah selanjutnya adalah:

b. Mencari rentang (tabel range) yaitu untuk dijadikan sebagai patokan dalam menentukan kelas interval dan panjang interval dan diperoleh angka rentang sebesar 29. Angka tersebut diperoleh dari perhitungan $X_{t}-X_{r}+1$.

c. Mencari kelas interval (K) diperoleh hasil angka 6 yaitu hasil perhitungan dari $1+33 \log N$.

d. Mencari panjang interval (P) diperoleh hasil angka 5 yaitu hasil perhitungan dari rentang kelas interval atau dengan rumus $\mathrm{R} / \mathrm{K}$.

e. Membuat tabel distribusi frekuensi yang terdiri dari beberapa kolom:

Kolom pertama (kelas interval)

Yang terdiri dari 7 kelas, mulai dari nilai terendah sampai nilai tertinggi dengan panjang interval masing-masing 10.

Kolom kedua frekuensi (f) dari masing-masing kelas interval. 
Kolom ketiga $(\mathrm{X})$ ialah nilai titik tengah (mid point) yaitu dengan cara menjumlahkan nilai yang ada pada masing-masing kelas interval dibagi dua. Kolom keempat $\left(\mathrm{X}_{1}^{2}\right)$ yaitu kuadrat dari nilai titik tengah (mid point) di atas. Kolom kelima $\left(f_{1} \mathrm{X}_{1}\right)$ yaitu hasil perkalian dari frekuensi dan nilai titik tengah. Kolom keenam $\left(f_{1} \mathrm{X}_{1}^{2}\right)$ yaitu kuadrat dari hasil perkalian frekuensi dan titik tengah.

Kolom ketujuh (fka) atau frekuensi kumulatif atas ialah hasil penjumlahan masing-masing frekuensi yang dimulai dari atas.

Kolom kedelapan (fkb) yaitu frekuensi kumulatif bawah ialah hasil penjumlahan masing-masing frekuensi yang dimulai dari bawah.

Kolom kesembilan ialah selisih deviasi (d).

Yang menjadi patokan pertama adalah nilai tertinggi dari nilai titik tengah yaitu 76. Dan selanjutnya baik nilai 76 sendiri begitu juga nilai-nilai ke atas dan ke bawah masing-masing dikurangi 76, yang hasilnya akan terlihat pada kolom ini.

Kolom kesepuluh ialah (fd) hasil perkalian dari frekuensi (f) dan selisih deviasi.

Kolom kesebelas yaitu $\left(\mathrm{fd}^{2}\right)$ ialah hasil perkalian dari frekuensi (f) dan kuadrat selisih deviasi (d).

f. Menentukan harga mean (m).

Harga mean dapat diperoleh dari jumlah hasil perkalian frekuensi dari nilai titik tengah (mid point) atau $\sum f_{1} \mathrm{X}_{1}$ dibagi jumlah $\sum f_{1}$ diperoleh hasilnya ialah 73.

Menentukan median (md) yaitu hasil kali $1 / 2 n$ dikurangi frekuensi kumulatif bawah median atau

$B b+P=\frac{(1 / 2 n-f k b)}{\mathrm{F}}$ diperoleh hasil 74,4.

g. Menentukan modus (mo) yaitu 3 kali median -2 kali mean atau $3 \mathrm{md}-2 \mathrm{~m}$ diperoleh hasil 77,2.

h. Membuat kurva.

Karena berdasarkan perhitungan di atas harga mean lebih kecil dari median dan median lebih kecil dari modus, maka kurva tersebut berbentuk juling 
negatif atau berposisi mendekati normal. Bentuk kurva yang berposisi negatif berarti menunjukkan bahwa nilai-nilai yang diperoleh lebih banyak bertumpu pada nilai-nilai tinggi.

i. Menentukan standar deviasi (SD)

Yaitu hasil perkalian dari panjang interval terhadap akar dari jumlah kuadrat frekuensi kali selisih deviasi dibagi jumlah sampel dikurangi jumlah frekuensi kali selisih deviasi dibagi jumlah sampel kuadrat atau

$S D=\sqrt{\sum \frac{f d^{2}}{N}-\frac{(\Sigma \mathrm{fd})^{2}}{N}}$ diperoleh hasil 6,53.

j. Membuat tabel frekuensi observasi dan ekspektasi yang terdiri dari delapan kolom.

Kolom 1 adalah kelas dan panjang interval yang terdiri dari nilai terendah sampai nilai tertinggi.

Kolom 2 adalah frekuensi dari nilai-nilai tersebut.

Kolom 3 adalah batas nyata hasil dari pengurangan dan penambahan terhadap nilai-nilai yang terdapat pada kelas interval, nilai rendah dikurangi 0,5 dan nilai tinggi ditambah 0,5 . Jadi kalau nilai pada kelas interval 87 - 91 maka batas nyatanya berarti $86,5-91,5$.

Kolom 4 adalah mencari (luas kelas) ${ }^{2}$ hitung yaitu hasil dari selisih batas nyata dikurangi mean dibagi standar deviasi (SD)

$Z=\frac{X-X}{S D}$

Kolom 5 mencari luas kelas dari tabel-tabel (2 tabel).

Kolom 6 adalah selisih luas kelas.

Kolom 7 ialah hasil dari selisih kelas dikalikan jumlah sampel atau $f e=s k \times N$.

Kolom 8 ialah nilai chi kuadrat yaitu hasil dari kuadrat frekuensi (f) dikurangi selisih kelas kali jumlah sampel dibagi fe atau $X=\frac{(f-f e)^{2}}{f e}=6,509$

k. Menentukan derajat kebebasan

Ialah hasil pengurangan dari kelas interval dikurangi 3 diperoleh hasil $(7-3=4)$. 
1. Menentukan chi kuadrat tabel pada taraf signifikansi 5\% diperoleh hasilnya sebesar 13,277 .

m. Penentuan normalitas

Berdasarkan perhitungan di atas diperoleh hasil chi kuadrat hitung sebesar 6,509 dan chi kuadrat tabel sebesar 13,277 berarti $\mathrm{X}_{\mathrm{ht}}^{2}<$ dari $\mathrm{X}_{\mathrm{tb}}^{2}$ hal itu dapat diinterpretasikan bahwa prestasi mahasiswa yang berlatar belakang pendidikan SMUN dalam mata kuliah Bahasa Arab berdistribusi normal.

\section{Perbedaan Prestasi Mahasiswa yang Berlatar Belakang Pendidikan MAN} dan Mahasiswa yang Berlatar Belakang Pendidikan SMUN dalam Mata Kuliah Bahasa Arab.

Setelah diketahui bahwa distribusi dari kedua tabel di atas normal, maka langkah selanjutnya untuk mengetahui apakah ada perbedaan mean dari kedua sampel di atas, maka perlu diuji lagi homoginitas dari kedua variansinya dengan langkah-langkah sebagai berikut:

1. Mencari nilai f sama dengan variansi dibagi variansi kecil atau hasil kuadrat dari standar deviasi variabel $\mathrm{X}$ dibagi kuadrat standar deviasi variabel $\mathrm{Y}$, maka diperoleh hasil $\mathrm{f}=1,36$.

2. Mencari derajat kebebasan dari kedua variabel di atas, maka diperoleh hasil derajat kebebasan variabel $\mathrm{X}$ sebesar 89 dan derajat kebebasan variabel Y sebesar 29.

3. Mencari nilai f pada tabel dengan taraf signifikansi 5\% maka diperoleh hasil nilai f tabel sebesar 2,17.

4. Penentuan Homoginitas

Setelah diperoleh hasil $\mathrm{f}$ hitung sebesar 1,36 dan f tabel sebesar 2,17, maka dapat diinterprestasikan bahwa kedua variansinya homogin.

Setelah diketahui bahwa distribusi dari kedua variabel tersebut normal dan kedua variansinya homogin maka untuk mengetahui perbedaan dari kedua variabel di atas penulis menggunakan rumus t. (Endi Nugraha, hal.21)

Adapun langkah-langkahnya adalah sebagai berikut:

1. Memanfaatkan mean variabel $\mathrm{X}$ maka diperoleh nilai $m_{\mathrm{x}}=7389$

2. Memanfaatkan mean variabel $\mathrm{Y}$ diperoleh nilai $m_{\mathrm{y}}=73$ 
3. Menentukan standar deviasi $\mathrm{V}_{\mathrm{x}}$ diperoleh nilai standar deviasi variabel $\mathrm{X}$ atau $\mathrm{sd}_{\mathrm{x}}$ sebesar 7,62.

4. Menentukan standar deviasi $\mathrm{V}_{\mathrm{y}}$ maka diperoleh nilai sebesar 6,53.

5. Mencari nilai standar error mean variabel $X$ yaitu standar deviasi $X\left(\operatorname{sd}_{x}\right)$ dibagi jumlah sampel $\mathrm{X}\left(\mathrm{N}_{\mathrm{x}}\right)$ diperoleh hasil sebesar 0,81 .

6. Mencari standar error mean variabel $\mathrm{Y}$ yaitu standar deviasi $\mathrm{Y}\left(\mathrm{sd}_{\mathrm{y}}\right)$ dibagi jumlah sampel $\mathrm{Y}\left(\mathrm{N}_{\mathrm{y}}\right)$ diperoleh hasil sebesar 1,21.

7. Mencari standar error perbedaan mean variabel $\mathrm{X}$ dan $\mathrm{Y}$, yaitu hasil dari akar kuadrat standar error mean $\mathrm{V}_{\mathrm{x}}\left(\mathrm{SEM}_{\mathrm{x}}\right)$ ditambah kuadrat standar error mean $\mathrm{V}_{\mathrm{y}}\left(\mathrm{SEM}_{\mathrm{y}}\right)$, diperoleh hasil sebesar 1,42.

8. Menetukan harga t hitung (observasi).

Harga t hitung diperoleh dari hasil pengurangan antara mean variabel $\mathrm{X}$ dan mean variabel Y dibagi hasil standar error perbedaan maka diperoleh hasil sebesar 0,627 .

9. Mencari derajat kebebasan $d f=(90+30)-2=118$.

10. Mencari harga $t$ tabel pada taraf signifikansi $1 \%$ diperoleh angka sebesar 2,62 dan pada taraf signifikansi 5\% diperoleh angka 1,98.

\section{Pengujian hipotesis}

Berdasarkan perhitungan di atas diperoleh angka t hitung sebesar 0,627 dan angka $t$ tabel $\left(\mathrm{t}_{\mathrm{t}}\right)$ sebesar 2,62 (pada taraf signifikansi 5\%). Hal itu berarti bahwa pada taraf signifikan $5 \% \mathrm{t}_{\mathrm{o}}$ lebih kecil dari $\mathrm{t}$ tabel $\left(\mathrm{t}_{\mathrm{t}}\right)$ yang berarti $\mathrm{H}_{\mathrm{o}}$ (hipotesis nihil) yang mengatakan tidak adanya perbedaan antara kedua variabel tersebut diterima dan $\mathrm{H}_{\mathrm{o}}$ (hipotesis alternatif) ditolak.

Dari hasil pengujian hipotesis di atas, menunjukkan bahwa antara prestasi mahasiswa yang berasal dari Madrasah Aliyah Negeri dan mahasiswa yang berlatar belakang pendidikan Sekolah Menengah Umum Negeri dalam mata kuliah Bahasa Arab perbedaannya tidak signifikan.

Hal ini tidak sesuai dengan hipotesis yang penulis ajukan pada bagian pendahuluan dimana penulis mengajukan hipotesis, bahwa antara prestasi mahasiswa yang berasal dari MAN dan SMUN dalam mata kuliah Bahasa Arab ada perbedaan. 


\section{KESIMPULAN}

1. Prestasi mahasiswa yang berlatar belakang pendidikan MAN, termasuk katagori baik karena memperoleh nilai sebesar 73,89 yaitu nilai yang terletak antara norma skala angka $70-79$. Hal itu diperoleh dari rentang nilai terendah 57 dan nilai tertingginya 89.

2. Prestasi mahasiswa yang berlatar belakang pendidikan SMUN, juga termasuk pada katagori baik karena memperoleh nilai rata-rata 73 yaitu nilai yang terletak antara norma skala angka $70-79$. Hal itu diperoleh dari rentang nilai terendah 59 dan nilai tertingginya 87.

3. Perbedaan prestasi mahasiswa yang berlatar belakang pendidikan MAN dan SMUN, berdasarkan hasil analisis dan hasil perhitungan dengan menggunakan rumus $\mathrm{t}$ diperoleh nilai $\mathrm{t}$ observasi sebesar 0,627 dan tabel pada taraf signifikan 5\% dengan derajat kebebasan 118 diperoleh nilai sebesar 2,62 maka berdasarkan hasil pengujian hipotesis menunjukkan bahwa, kalau to lebih kecil dari t tabel itu berarti bahwa Ho (hipotesis nihil) diterima dan $\mathrm{Ha}$ (hipotesis alternatif) ditolak. Hal itu berarti bahwa antara prestasi mahasiswa yang berlatar belakang pendidikan MAN dan SMUN dalam bidang studi Bahasa Arab perbedaannya tidak signifikan. 


\section{DAFTAR PUSTAKA}

Abin Syamsudin Makmun. 2003. Psikologi Pendidikan. Bandung: PT Rosda Karya Remaja

Anas Sudijono, 1997, Pengantar Statistik Pendidikan, Jakarta: Raja Drafindo Persada

Anonim. 2008. “Belajar Seumur Hidup”. http://gurupkn.wordpress.com. (Diakses Arikunto Suharsimi, 1988, Dasar-dasar Evaluasi Pendidikan, Jakarta: Bumi Aksara. Ahmadi, Abu dkk. 2013. Psikologi Belajar. Jakarta: Rineka Cipta

Arikunto Suharsimi. 2010. Prosedur Penelitian suatu pendekatan Praktik. Jakarta: PT. Rineka Cipta

Endi Nugraha, Drs, 1985, Statistik untuk Penelitian, Bandung: CV. Permadi

H. Ihsan Fuad. 2008. Dasar-Dasar Pendidikan. PT. Rineka Cinpta, Jakarta Roosdi Achmad Syuhada. 1988. Bimbingan dan Konseling dalam Masyarakat dan Pendidikan Luar Sekolah. Jakarta: Depdikbud.

Hamalik, Oemar. 2002. Psikologi Belajar. Bandung: Sinar Baru

Idris,Safwan,dkk, 1996, Studi Korelasi Antara Hasil tes masuk dan Prestasi belajar Mahasiswa IAIN Ar-Raniri, Banda Aceh ; Laporan hasil Penelitian Proyek Peningkatan Perguruan Tinggi Agama IAIN Ar-Raniry.

Juni 2010)

Makmun, Abin Syamsudin, 1996, Psikologi Pendidikan: Bandung, Remaja Rosdakarya.

Mudjono, Dimyati. 2009. Belajar dan pembelajaran. Djogakarta. Rineka cipta

Nasution, Nuhi, 1991, Psikologi Pendidikan, Jakarta: Direktorat Jendral Pembinaan Kelembagaan Islam Universitas Terbuka.

Nur, Baharudin. 2007. Teori Belajar dan pembelajaran. Jogjakarta. Arruz Media Purwanto. 2004. Psikologi Pendidikan. Bandung: Remaja Rosdakarya

Singaribuan, Masri Dan Sofian Efendi, 1987, Metoda Penelitian Survai, Yogyakarta: Lembaga Penelitian, Pendudikan dan penerangan Ekonomi dan Sosial.

Slameto. 2003. Belajar dan Faktor-Faktor yang Mempengeruhinya. Jakarta: Rineka Cipta 
Soelaiman Joesoef. 1986. Konsep Dasar Pendidikan Luar Sekolah. Surabaya: PT Bumi Aksara

Sudjana, 1990, Metoda Statistika, Bandung: Tarsito.

Sukiman. 2012. Pengembangan Sistem Evaluasi. Yogyakarta: Insan Madani

Surakhmad, Winarno, 1990, Pengantar Penelitian Ilmiah, Bandung: Tarsito.

Syah, Muhibin. 1995, Pendidikan Suatu Pendekatan Baru, Bandumg Remaja Rosdakarya.

Winkel, W.S., 1964, Psikologi Pengajaran, Jakarta: Gramedia. Ahmadi Abu. Ubiyati Nur. Dasar-dasar Pendidikan. 191 :2003: Ilmu Pendidikan. PT. Rineka Cipta. Jakarta. 